\title{
The Information Technology (IT) Skills of Hospitality School Graduates as Perceived by Hospitality Professionals
}

\author{
Katerina Berezina \\ Oklahoma State University, \\ Anil Bilgihan \\ University of Central Florida, \\ Cihan Cobanoglu \\ University of South Florida Sarasota-Manatee, \\ and \\ Fevzi Okumus \\ University of Central Florida
}

\begin{abstract}
Hospitality schools aim to provide their graduates with the skills and tools that are necessary to succeed in a rapidly changing and developing industry environment (Swanger \& Gursoy, 2010). Given that information technology (IT) applications have become an essential part of hotel operations, this paper investigates industry perspective on the IT skills of hospitality school graduates. 110 industry professionals have participated in the study. The findings of this study are useful to hospitality educators in making sure that the information technology skills needed by the industry from hospitality school graduates are covered in curriculum. A significant gap between the importance scores of different skills reported by industry professionals' and their evaluation of recent graduates' performance shows that there is a need to improve students' IT skills. The results of the study indicate that hospitality schools student need better preparation in the areas of "using spreadsheet programs (i.e. Microsoft Excel)", "using email systems (i.e. Outlook Express, Thunderbird)", "using word processing programs (i.e. Microsoft Word)", "Presenting data in an efficient manner", "using point of Sale Systems (i.e. Micros), and "analyzing numerical data with computers (i.e. SPSS, Excel)."
\end{abstract}

Keywords: teaching, hotel technology applications, hospitality education

\section{INTRODUCTION}

The adoption of the information technology (IT) in the hospitality industry started in early 1970s and has been rapidly developing ever since (Collins and Cobanoglu, 2008; Kasavana and Cahill, 2007; Sammons, 2000). Different systems implemented in the industry provided a basis for competitive advantage, productivity improvement, enhanced financial performance, and guest service expansion (Collins and Cobanoglu, 2008; Kim, Lee, and Law, 2008; Kasavana and Cahill, 2007; Siguaw, Enz, and Namasivayam, 2000). Given this, IT in tourism education might give the necessary skills to potential managers in the industry. Graduates of hospitality schools have to use computer applications in their working environment, some of those applications are critical for marketing strategies whereas, some of them are used for daily routines such as checking in a customer to the hotel or entering the food that customers ordered to the point of sale system (Collins \& Cobanoglu, 2008). 
This structured inquiry study highlights on the types of common information technology (IT) competencies that are essential in the hospitality industry. The study tries to answer questions such as: Should hospitality schools offer IT courses? What skills are important for hospitality schools students to obtain during the education as perceived by the industry professionals? What is the level of hospitality school recent graduates IT performance as perceived by industry professionals?

\section{LITERATURE REVIEW}

\section{Information Technology in Hotels}

Researchers stress the importance of technology for the hospitality industry and highlight that it has became an indispensable part of hotels' everyday operations (Collins \& Cobanoglu, 2008; Ham, Kim, \& Jeong, 2005; Kasavana \& Cahill, 2003; Squires, 2008). Interestingly, the bigger a hotel and the wider the number of services provided (restaurants, sport facilities, spa centers, golf courses, etc.) the higher reliance on technology (Piccoli \& Torchio, 2006; Siguaw, Enz, \& Namasivayam, 2000). This happens because technology has entered all the spheres of hotels' life influencing both back of the house and front of the house operations (Kasavana \& Cahill, 2003). One application that addresses different back and front office functions and has had a significant impact on overall hotels' operation is a property management system (PMS) (Collins \& Cobanoglu, 2008).

Back of the house technologies include essential processes and operations that cover hotels internal communication that do not involve guests (Kasavana \& Brooks, 1995). Back office packages may include numerous applications and differ depending on the operations performed (Kasavana \& Cahill, 2003). Such packages can consist of several modules such as accounts payable/receivable, payroll, inventory and purchasing accounting, reports module. In other words, these technologies help to manage all financial activities of the property that occur between a hotel and its employees, partners, vendors, different financial institutions and customers.

Technology adoption enables Human Resources managers to handle employees' queries, organize databases, communication, training, and develop reward programs (Rutherford \& O'Fallon, 2007). One of considerable problems of the hospitality industry is employee turnover. Hinkin and Tracey (2006) described the web-based tool that can help to estimate the overall cost of employee turnover and develop "industry norms for turnover-related factors, such as wages, training duration, recruiting practices, drug testing, orientation programs and many other humanresources practices" (p. 9).

Technology has plays an important role in hotels' revenue management activities (Squires, 2008). Automation helps managers to get accurate reports about pricing recommendations to reach higher profitability and to leave more room for analytical work. All the decisions taken within revenue management programs are usually implemented by means of reservation systems.

Proper handling of reservations is an essential and critical issue for hotels' successful operations (Kasavana \& Cahill, 2003). In other words, a reservation module is one of the crucial 
applications of PMS that enables managers to check room availability, place individual and group reservations, generate confirmations and handle numerous other functions (Collins \& Cobanoglu, 2008). A central reservation system (CRS) is an important asset for a hotel chain that provides a unique platform for chain reservations. To broaden distribution channels and increase occupancy rates, property (or central) reservation systems may be interfaced to the Internet reservation module, enabling customers to book hotel rooms on-line on the corporate web-site; and global distribution systems, providing an opportunity for travel agents worldwide to make their reservations in real time.

\section{Bridge between Hospitality Education and Industry}

Hospitality schools aim to provide their graduates with the skills and tools that are necessary to succeed in a rapidly changing and developing industry environment (Swanger \& Gursoy, 2010). The results of the study investigating an industry-driven model of hospitality curriculum indicated Computer/Information Technology subjects to be ranked among the top ten the most important for students' success.

IT skills and competencies required by tourism professionals can be collapsed into three categories: (a) industry-specific applications, (b) end-user applications, and (c) conceptual and strategically focused applications (Buhalis \& O’Connor, 2001).

\section{Industry-Specific Applications}

These applications are the ones which are used only in the hospitality industry and designed for hospitality majors that they will exclusively for use in the hospitality industry. Students might learn how to use Property Management Systems (PMS) by using Fidelio. That training could be included in core hospitality courses. However, those applications are mainly focused to increase operational efficiency. As a result, their function as a strategic tool in managerial decision making is limited. However, according to Nadkarni (2004) training students is important because they will be using similar systems once they graduate and start to work in the hospitality industry.

\section{End-User Applications}

End-User applications are the general software that should be taught in the beginning stages of the hospitality programs. The course content is primarily targeted at students with little or no exposure to basic computer operations (Nadkarni, 2003). The end-user skills can be listed as word processing (e.g. Microsoft Word), presentation tools (e.g. Microsoft Power Point), online communications, scheduling and e-mail (e.g. Outlook, Thunderbird). The training for that software would be important for students in their careers and lives. These topics constitute the syllabus of Introduction to Computers I \& II, which are noncore subjects taught in the first year of study at IFT to students of both hotel and tourism streams (Nadkarni, 2003). Likewise industry specific applications, those software training is also do not affect the strategic thinking directly. As an IT instructor, I would recommend hospitality schools to include a course that focuses on end-user applications. 


\section{Conceptual and Strategically Focused Applications}

Opposing, this group offers strategic decision making tools. These applications are useful for planning, data collection and preparation, modeling, forecasting, optimizing, and reporting (Nadkarni, 2003). Data collection, data warehousing, and data mining subjects are introduced as Information Systems Management taught at the year 3 level. These skills from that class are beneficial for decision making in marketing and finance. Additionally, SPSS can be included in syllabuses for hospitality schools. With SPSS training, students can make strategic marketing analysis.

Literature suggests that there has been a gap between what is needed by the industry and what was being taught in hospitality schools which to an extent. For instance, Cheung and Law (2002) pointed out a gap between the level of technology education that hospitality schools offer and the levels of technology knowledge that the industry expects from students. King, McKercher, and Waryszak (2003) conducted a comparative study of Hospitality and Tourism Graduates in Australia and Hong Kong and found that information technology was one of the courses that did not exist in both Australian and Hong Kong hospitality schools' curriculum. Nadkarni (2003) investigated the factors that attributed to the gap between what is being taught and what ought to be taught in tourism business management education. These expectations are transferred to hospitality education settings, particularly into technology courses or technologically enhanced courses, such as Web-based curriculum (Collins, 2004). The overall objective of this study was to further clarify this gap and explore the competencies and IT skills that are expected from recent hospitality schools graduates entering the operational positions in hotels which hospitality programs need to incorporate into their curriculum.

\section{Problem Statement}

The review of relevant literature revealed numerous information technology applications being employed in different aspects of hotel operations as well as industry's importance granted to the computer and information technology subjects in the hospitality schools' curriculum. Based on this, the researchers would like to investigate and answer the following research questions:

1. What is the level of importance of information technology skills for hospitality school graduates as viewed by industry professionals?

2. What is the level of industry professionals' satisfaction with the information technology skills demonstrated by recent hospitality school graduates?

3. Is there a gap between the level of importance of information technology skills and the level of satisfaction with the information technology skills demonstrated by recent hospitality school graduates as indicated by industry professionals?

\section{METHODOLOGY}

An online survey was utilized for the purpose of the study. A questionnaire with an invitation to participate in the study was mailed to randomly selected 1000 industry professionals from a national database of U.S hospitality professionals. The survey included three following 
parts. The first part of the questionnaire was designed to assess the level importance and satisfaction with the level of information technology skills that the hospitality school graduates demonstrate. The second part included attitudinal questions about the IT departments and their structure in hotels. The last section contained demographical questions. The data was collected from March 2010 to May 2010.

\section{FINDINGS}

Out of the 1000 hospitality professionals, 152 hotel industry professionals replied to the survey, yielding a $15.2 \%$ response rate. Forty two responses were not complete and thus eliminated from the study. One hundred ten useful responses yielded $11 \%$ net response rate. Non-response bias analysis requires comparison of non-respondents with respondents of the study. Rylander, Propst, and McMurtry (1995) suggested that late respondents and nonrespondents were alike and wave analysis and respondent/non-respondent comparisons yield the same results. Based on this, late respondents were used as a proxy for non-respondents and a non-response analysis using wave analysis (early versus later respondents) was conducted to determine, (1) whether non-respondents and respondents differed significantly, (2) whether equivalent data from those who did not respond would have significantly altered the findings. For this purpose all respondents were divided into two groups according to the date they filled out the questionnaire. An independent sample t-test showed that there is no significant difference between the mean scores of importance and performance of IT skills. After concluding that the sample does not suffer from non-response bias, the research proceeded with data analysis.

\section{Demographics}

Among 110 hospitality executives who participated in the study the most frequently reported job position was Treasurer/Controller/Chief Financial Officer (32.7\%), followed by General Manager (11.8\%) and Technology Director/IT Manager/ IS Manager and Director/Assistant Assistant Director/Section Head that accounted for $10 \%$ each. Majority of the respondents held an undergraduate degree (58.2\%), however, only $20.9 \%$ of all respondent have a Bachelor's degree in hospitality. Majority of the study participants represented upscale segment of the hotel industry (50.9\%). Almost two thirds of the respondents $(74.5 \%)$ do hire hospitality schools graduates. Full respondents' demographic characteristics are presented in the Table 1 below. 
Table 1

Respondent demographic characteristics

\begin{tabular}{|c|c|c|c|}
\hline Variable & $\%$ & Variable & $\%$ \\
\hline Job Position & & Property's Segment & \\
\hline CEO and/or President & 8.2 & Luxury & 14.5 \\
\hline General Manager & 11.8 & Upscale & 50.9 \\
\hline Vice President/Assistant Vice President & 7.3 & Mid-price & 20.9 \\
\hline Chief Information Officer/ Chief Technology Officer (corp.) & 2.7 & Budget & .9 \\
\hline Technology Director/IT Manager/ IS Manager (prop.) & 10.0 & Economy & 3.6 \\
\hline Director/Assistant Assistant Director/Section Head & 10.0 & Other & 23.6 \\
\hline Front Office Manager/Assistant FO Manager & .9 & Total & 100.0 \\
\hline Treasurer/Controller/Chief Financial Officer & 32.7 & & \\
\hline Restaurant Manager/F\&B Manager/Assistant F\&B Manager & .9 & Property's Type & \\
\hline Other Department Manager/Assistant Manager & 2.7 & Convention Hotel & 14.5 \\
\hline Other & 12.7 & Standard Hotel & 18.2 \\
\hline \multirow{2}{*}{ Total } & 100.0 & All suite & 5.5 \\
\hline & & Extended stay & .9 \\
\hline Highest Level of Education & & Conference Center & 1.8 \\
\hline High School Degree & .9 & Resort & 20.0 \\
\hline Certificate or Diploma & 6.4 & Club & 8.2 \\
\hline Associate Degree & 5.5 & Other & 30.9 \\
\hline Bachelor's Degree & 58.2 & Total & 100.0 \\
\hline Graduate Degree & 27.3 & & \\
\hline Doctoral Degree & 1.8 & Number of Rooms & \\
\hline \multirow[t]{2}{*}{ Total } & 100.0 & Less than 100 rooms & 12.7 \\
\hline & & $100-200$ rooms & 30.9 \\
\hline Do you have a hospitality degree (4 year) & & 201-300 rooms & 15.5 \\
\hline Yes & 20.9 & $301-400$ rooms & 7 \\
\hline No & 79.1 & More than 400 rooms & 32.5 \\
\hline Total & 100.0 & Total & 100.0 \\
\hline Age & & Years of experience in the hospitality & \\
\hline $21-25$ & 4.5 & $1-3$ years & 5.5 \\
\hline $26-30$ & 5.5 & $3-5$ years & 5.5 \\
\hline $31-40$ & 14.5 & $5-10$ years & 13.6 \\
\hline $41-50$ & 40.0 & More than 10 years & 75.5 \\
\hline $51-60$ & 28.2 & Total & 100.0 \\
\hline Older than 60 & 7.3 & & \\
\hline \multirow[t]{2}{*}{ Total } & 100.0 & One-unit/Multi-unit Responsibility & \\
\hline & & Single Unit & 43.6 \\
\hline Do you hire hospitality school graduates? & & Multi-Unit & 56.4 \\
\hline Yes & 74.5 & Total & 100.0 \\
\hline No & 25.5 & & \\
\hline Total & 100.0 & & \\
\hline & & & \\
\hline
\end{tabular}

\section{$\mathbf{N}=110$}

Research Question 1. What is the level of importance of information technology skills for hospitality school graduates as viewed by industry professionals?

The findings of this research show that the top five important information technology skills for hospitality school graduates are "use spreadsheet programs (i.e. Microsoft Excel)", "use 
email systems (i.e. Outlook Express, Thunderbird)", "use word processing programs (i.e. Microsoft Word)", "Present data in an efficient manner", "Point of Sale Systems (i.e. Micros), and "analyze numerical data with computers (i.e. SPSS, Excel)." The least important IT skills are "Publishing Software (i.e. Microsoft Publisher)", "Shopping on the Internet", "Nutrition Analysis Software", "Audio recording and editing (i.e. Audio Podcast)", and "Video recording and editing." (See Table 2).

Research Question 2. What is the level of industry professionals' satisfaction with the information technology skills demonstrated by recent hospitality school graduates?

The results of the study show that hospitality graduate perform best in "Using email systems (i.e. Outlook Express, Thunderbird)", "Using spreadsheet programs (i.e. Microsoft Excel)", "Using word processing programs (i.e. Microsoft Word)", "Presenting data in an efficient manner" and "Using Point of Sale Systems (i.e. Micros)". Industry professional gave the lowest scores to the performance of the hospitality schools graduates in the following categories: "Create and maintain a computer network", "Project Management Software (i.e. Microsoft Project)", "Audio recording and editing (i.e. Audio Podcast)", "Nutrition Analysis Software", "Video recording and editing" (See Table 2).

Research Question 3. Is there a gap between the level of importance of information technology skills and the level of satisfaction with the information technology skills demonstrated by recent hospitality school graduates as indicated by industry professionals?

Even though the results of the study show that the most important and the most satisfying IT skills are the same, gap analysis demonstrates that industry expectations' are higher than graduates' performance. This is true in most cases: the results show no significant difference between importance and performance scores only for "Audio recording and editing", Publishing software (e.g. Microsoft Publisher)", "Social networking tools (e.g. blogs, wikis, Facebook)" and "Video recording and editing". A comparison of the mean scores for all other IT skills revealed a significant difference. In most cases industry professionals evaluated graduates' performance lower than they would expect. The only skill with higher performance than importance was found to be "Shopping on the Internet". 
Table 2

Gap analysis between importance and performance of IT skills

\begin{tabular}{|c|c|c|c|c|c|c|c|c|}
\hline & \multicolumn{2}{|c|}{ IMPORTANCE (I) } & \multicolumn{2}{|c|}{$\begin{array}{r}\text { PERFORMANCE }(\mathrm{P}) \\
\text { Std. }\end{array}$} & \multirow[t]{2}{*}{$\begin{array}{l}\text { Difference } \\
(\mathrm{I}-\mathrm{P})\end{array}$} & \multirow[t]{2}{*}{$\mathrm{t}$} & \multirow[t]{2}{*}{ df } & \multirow[t]{2}{*}{$\begin{array}{l}\text { Sig. (2- } \\
\text { tailed) }\end{array}$} \\
\hline & Mean & Std. Deviation & Mean & Deviation & & & & \\
\hline Analyze numerical data with computers (i.e. SPSS, Excel) & 4.45 & 0.762 & 3.59 & 1.095 & 0.86 & 7.748 & 109 & $0.000 *$ \\
\hline Audio recording and editing (i.e. Audio Podcast) & 2.5 & 1.115 & 2.4 & 1.077 & 0.1 & 1.13 & 109 & 0.261 \\
\hline Business Intelligence Software (i.e. Cognos, Mirus) & 3.27 & 1.188 & 2.89 & 1.251 & 0.38 & 4.182 & 109 & $0.000 *$ \\
\hline Central Reservation System (i.e. MARSHA, OnQ, Holidex) & 3.85 & 1.11 & 3.23 & 1.261 & 0.62 & 5.938 & 109 & $0.000 *$ \\
\hline Cost Control/Inventory Software & 3.71 & 1.087 & 3.12 & 1.262 & 0.59 & 5.308 & 109 & $0.000 *$ \\
\hline Create and update a website & 2.94 & 1.258 & 2.73 & 1.188 & 0.21 & 2.287 & 109 & $0.024 * *$ \\
\hline Delete virus and spyware & 3.59 & 1.28 & 3.01 & 1.324 & 0.58 & 5.571 & 109 & $0.000 *$ \\
\hline Evaluate the role of IT systems in the industry & 3.51 & 1.217 & 2.95 & 1.222 & 0.56 & 5.147 & 109 & $0.000 *$ \\
\hline Explain why computer program does not work & 3.35 & 1.215 & 3.04 & 1.219 & 0.31 & 3.538 & 109 & $0.001 *$ \\
\hline Global Reservation System (i.e. Sabre, Gallileo, Amadeus) & 3.73 & 1.149 & 3.13 & 1.279 & 0.6 & 5.938 & 109 & $0.000 *$ \\
\hline Hospitality E-purchasing System & 3.63 & 1.099 & 3.06 & 1.198 & 0.57 & 5.234 & 109 & $0.000 *$ \\
\hline Install computer software & 3.52 & 1.297 & 3.1 & 1.285 & 0.42 & 4.133 & 109 & $0.000 *$ \\
\hline Online marketing tools & 3.41 & 1.144 & 2.95 & 1.128 & 0.46 & 4.636 & 109 & $0.000 *$ \\
\hline Participate in virtual meetings (ie. Webinars, teleconference) & 3.97 & 1.009 & 3.55 & 1.106 & 0.42 & 4.525 & 109 & $0.000 *$ \\
\hline Point of Sale Systems (i.e. Micros) & 4.46 & 0.762 & 3.74 & 1.155 & 0.72 & 6.687 & 109 & $0.000 *$ \\
\hline Present data in an efficient manner & 4.51 & 0.726 & 3.75 & 1.085 & 0.76 & 6.565 & 109 & $0.000 *$ \\
\hline Project Management Software (i.e. Microsoft Project) & 2.96 & 1.116 & 2.65 & 1.105 & 0.31 & 3.675 & 109 & $0.000 *$ \\
\hline Property Management Systems (i.e. Fidelio, FOSSE) & 4.04 & 1.165 & 3.4 & 1.236 & 0.64 & 6.542 & 109 & $0.000 *$ \\
\hline Publishing Software (i.e. Microsoft Publisher) & 2.88 & 1.107 & 2.78 & 1.07 & 0.1 & 1.291 & 109 & 0.199 \\
\hline Shopping on the Internet & 2.74 & 1.325 & 3.09 & 1.296 & -0.35 & -3.179 & 109 & $0.002 *$ \\
\hline Social Networking Tools (i.e. blogs, wikis, Facebook, Flicker) & 3.14 & 1.288 & 3.29 & 1.295 & -0.15 & -1.408 & 109 & 0.162 \\
\hline System Selection and Implementation & 3.49 & 1.247 & 2.89 & 1.35 & 0.6 & 5.253 & 109 & $0.000 *$ \\
\hline Understand the latest IT trends in the industry & 3.62 & 1.117 & 3.08 & 1.142 & 0.54 & 5.331 & 109 & $0.000 *$ \\
\hline Use database programs (i.e. Microsoft Access) & 3.36 & 1.073 & 2.95 & 1.104 & 0.41 & 4.706 & 109 & $0.000 *$ \\
\hline Use email systems (i.e. Outlook Express, Thunderbird) & 4.77 & 0.519 & 4.16 & 1.036 & 0.61 & 6.354 & 109 & $0.000 *$ \\
\hline Use graphic drawing programs (i.e. Photoshop) & 2.95 & 1.061 & 2.69 & 1.029 & 0.26 & 2.956 & 109 & $0.004 *$ \\
\hline Use presentation programs (i.e. Microsoft PowerPoint) & 4 & 0.995 & 3.54 & 1.098 & 0.46 & 4.994 & 109 & $0.000 *$ \\
\hline Video recording and editing & 2.46 & 1.147 & 2.35 & 1.072 & 0.11 & 1.228 & 109 & 0.222 \\
\hline
\end{tabular}

$\mathrm{N}=110, * \mathrm{p}<0.01, * * \mathrm{p}<0.05$ 


\section{CONCLUSIONS}

The findings of this study are useful to hospitality educators in making sure that the information technology skills needed by the industry from hospitality school graduates are covered in curriculum. A significant gap between the importance scores of different skills reported by industry professionals' and their evaluation of recent graduates' performance shows that there is a need to improve students' IT skills. The results of the study indicate that hospitality schools student need better preparation in the areas of "using spreadsheet programs (i.e. Microsoft Excel)", "using email systems (i.e. Outlook Express, Thunderbird)", "using word processing programs (i.e. Microsoft Word)", "Presenting data in an efficient manner", "using point of Sale Systems (i.e. Micros), and "analyzing numerical data with computers (i.e. SPSS, Excel)." The aforementioned skills received the highest importance scores, however, the gap analysis, revealed that industry professional rate students' performance in the same categories lower. Given the goal of hospitality schools to prepare students to the real life work, develop skills and knowledge necessary for success (Swanger \& Gursoy, 2010), the findings of the study will be useful and helpful to the hospitality schools' faculty in their effort in revision curriculum and building stronger programs.

\section{LIMITATIONS AND FUTURE RESEARCH}

Limitations of the study would include a small sample size. Collected data is not generalizable to the entire population of hotel professionals in the United States. However, the current study provides a useful insight into the problem of matching hospitality schools' curriculum and industry expectations.

The researchers would propose to conduct similar studies with hospitality schools' faculty and students in the United States in order to asses a gap between all three parties involved. 


\section{REFERENCES}

Buhalis, D., \& O'Connor, P. (2001). Opinion: IT in the tourism education curriculum. Tedqual/ WTO THEMIS Publication, No. 3/1/2001, 11-14.

Collins, G.R., \& Cobanoglu, C. (2008). Hospitality information technology: Learning how to use it $\left(6^{\text {th }}\right.$ ed.). Dubuque, IA: Kendall/Hunt Publishing Company.

Ham, S., Kirn, W. G., \& Jeong, S. (2005). Effect of information technology on performance in upscale hotels. International Journal of Hospitality Management, 24(2), 281-294.

Hinkey, T., \& Tracey, B. (2006). Development and use of a web-based tool to measure the costs of employee turnover: preliminary findings. Cornell Hospitality Report. 6(6).

Kasavana, M.L., \& Brooks, R.M. (1995). Managing front office operations $\left(4^{\text {th }}\right.$ ed.). Lansing, MI: Educational Institute of the American Hotel \& Lodging Association.

Kasavana, M.L., \& Cahill J.J. (2003). Managing technology in the hospitality industry (4 $4^{\text {th }} \mathrm{ed}$.). Lansing, MI: Educational Institute of the American Hotel \& Lodging Association.

Kim, T.G., Lee, J.H., \& Law, R. (2008). An empirical examination of the acceptance behavior of hotel front office systems: An extended technology acceptance model. Tourism Management, 29, p. $500-513$.

King, B., McKercher, B., \& Waryszak , R.(2003). A comparative study of hospitality and tourism graduates in Australia and Hong Kong. International Journal of Tourism Research, 5(6), $409-420$.

Nadkarni, S. (2003) Information Technology Competencies in Tourism management Education. Information technology \& Tourism. 6, 47-54.

Piccoli, G., \& Torchio, P. (2006). The strategic value of information: A manager's guide to profiting from information. Cornel Hospitality Report, 7(6).

Rutherford, D.G., \& O'Fallon, M.J. (2007). Hotel management and operations $\left(4^{\text {th }}\right.$ ed.). Hoboken, NJ: John Wiley \& Sons, Inc.

Sammons, G. (2000). Technology: How hospitality sales managers use and view it! Journal of Convention \& Exhibition Management, 2(2), 83.

Siguaw, J., Enz, C., \& Namasivayam, K. (2000). The adoption of information technology in U.S. hotels: Strategically driven objectives. Journal of Travel Research, 39, 192.

Squires, M. (2008). Technology changes lodging workforce. Lodging Hospitality, 64(16), 89-94.

Swanger, N., \& Gursoy, D. (2010). An industry-driven model of hospitality curriculum for programs housed in accredited colleges of business: e-assessment tool (e-AT) - part IV . Journal of Hospitality and Tourism Education, 22 (2), 5 - 19. 